\title{
Herbicide based weed management in aromatic rice of Bangladesh
}

\author{
A K M Mominul Islam ${ }^{1,2}$, Md. Azhiat-Ul Huq Hia ${ }^{1}$, Shubroto Kumar Sarkar ${ }^{2}$ and Md. Parvez \\ Anwar ${ }^{1,2}$
}

${ }^{1}$ Weed Management Laboratory, Department of Agronomy, Bangladesh Agricultural University, Mymensingh-2202, Bangladesh ${ }^{1,2}$ Department of Agronomy, Bangladesh Agricultural University, Mymensingh-2202, Bangladesh

\section{ARTICLE INFO}

Article history:

Received: 18 February 2018

Accepted: 05 April 2018

Keywords:

Late summer rice, fine rice, scented rice, weed injury level, weed biomass

Correspondence:

A K M Mominul Islam

(akmmominulislam@bau.edu.bd)

\begin{abstract}
Selection of appropriate weed management strategy helps reduce rice yield loss due to weeds. Despite some undesirable side-effects, no viable alternative is currently available to shift the chemical weed management in rice. However, time of herbicide application is very important with respect to its efficacy. Keeping in mind the inevitability of herbicidal weed control, the current study was designed to evaluate the response of selected aromatic fine rice varieties of Bangladesh to different herbicides based weed management practices compare to farmers' practices. The experiment was conducted in a randomized complete block design with three replications. The experiment consisted of five aromatic rice varieties; Kalijira, BRRI dhan34, BRRI dhan37, BRRI dhan38 and Binadhan-13, and six different weed management practices comprising no weeding, weed free, mechanical + manual weeding, pre-emergence herbicide + manual weeding, post-emergence herbicide + manual weeding and pre- + post-emergence herbicide. Eleven weed species belonging to five families were observed in the experimental plots. Based on the summed dominance ratio (SDR), grassy weed species Echinochloa crusgalli (SDR of 30.7) was the most dominant species, whereas broadleaf weed Nymphaea nouchali (SDR of 0.83) was the least one. Among the weed control treatments, application of pre-+ post emergence herbicides offered the highest reduction in weed density and biomass at all sampling dates which resulted in minimum crop-weed competition facilitating improvement in the yield contributing characters and finally resulted in the highest grain yield $\left(2.5 \mathrm{t} \mathrm{ha}^{-1}\right)$ and harvest index $(30.7 \%)$ next to the weed free treatment. The variety BRRI dhan 38 gave the highest grain yield $\left(3.4 \mathrm{t} \mathrm{ha}^{-1}\right)$ due to the highest performance of the yield contributing characters among the varieties. In interaction, BRRI dhan38 with pre-+ post-emergence herbicide application gave the highest yield $\left(3.4 \mathrm{t} \mathrm{ha}^{-1}\right)$ apart from the weed free treatment. Being efficient in weed density and biomass reduction as well as the highest yield producer, sequential application of pre- and post-emergence herbicides may be recommended for effective weed management practices in BRRI dhan 38 .
\end{abstract}

\section{Introduction}

Bangladesh agriculture is dominated by the rice farming of which aromatic rice has started to get the attention of the consumers. The distinct characteristic of this type of rice is the pleasant aroma while cooked. Aroma is one of the most important qualitative traits of rice grain responsible for the good market value of the produce. The biochemical basis of aroma was identified as 2acetyl-1-pyrroline (Tanchotikul and Hsieh, 1991). Because of the scented character the production of aromatic rice in Bangladesh is profitable demanding a high price over low price coarse milled rice (Raju and Reddy, 2000; Sikdar et al., 2008). Majority of the aromatic rice cultivars are low yielding but its higher price and low cost of cultivation generate higher profit margins compared to other varieties (Biswas et al., 2016). Besides the genetic constituents of the aromatic rice varieties, other biotic factors and different management practices could be responsible for the low yield of the aromatic rice cultivars. Among the biotic factors, weed is considered as one of the noxious enemies of crop wasting economic inputs worldwide. It is the most acute pest in agriculture with an estimated annual loss of around 40 billion USD per year worldwide (Monaco et al., 2002). Among the harmful pest, weeds contribute maximum losses in crop production, which may potentially reduce crop production by $34 \%$, followed by animal pests $(18 \%)$ and pathogens by $16 \%$ (Abbas et al., 2018). Weeds also rank first in reducing yields (34\%) of major crops world-wide (Jabran et al., 2015). On average 25 and 5\% production loss is caused by weeds in developing and developed countries, respectively; despite of any weed control measures (Koch, 1992). Rice yield reduction in Bangladesh is $70-80 \%$ (direct seeded Aus rice), $30-40 \%$ (transplanted Aman rice) and 22-36\% (modern Boro rice) (Mamun, 1990; BRRI, 2008).

Weeds compete for the natural resources e.g., light, water, space, and nutrient thereby reduce the crop growth, yield and quality (Ashiq and Aslam, 2014). Rao (2000) stated that an increase in one kilogram of weed biomass corresponds to a reduction in one kilogram of crop dry matter. The farmers of Bangladesh mainly practice conventional (manual i.e. hand pulling through niri or mechanical through rice weeder) methods of 
weeding, which are laborious and time consuming. However, these methods are now become difficult because of labour crisis at the peak period, which results in severe yield loss (Hasanuzzaman et al., 2009; Rashid et al., 2007). Therefore, farmers of the country are now going to be solely dependent on herbicidal weed control, which is quick, cost-effective and less laborious. As a result, the use of herbicides in the country has been $37-$ fold increase in the last three decades (BBS, 2017). However, uninterrupted use of the same herbicides for a long period may cause environmental hazards (Aktar et al., 2009, Islam and Kato-Noguchi, 2014), develop herbicide resistant weed biotypes (Heap, 2018), and cause shifts in weed flora (Holt, 1994). Despite such unwanted after effects, no viable alternative is currently available to shift the chemical dependence for weed management in rice. Herbicidal weed control is now considered as a viable alternative or supplement to conventional weeding (Mahajan et al., 2009; Chauhan and Johnson, 2011; Anwar et al., 2012). However, efficacy of an herbicide mainly depends on its ability to produce a desired effect on the target weeds. In addition, application time of herbicide is also very crucial with respect to its efficacy. Some other researchers stated that integration of more than one weed control methods i.e. integrated weed management is the best for efficient weed control due to its less effects on non-target organism, and for sustainable crop production (Singh et al., 2008; Jabran and Chauhan, 2015; Abbas et al., 2018).

Therefore, with a view to enhancing the proper crop growth for getting maximum grain yield by minimizing the crop-weed competition, efficient weed management practices should be practiced. Besides, the selection of appropriate variety is also essential for obtaining a good harvest because different varieties may vary in their canopy structure and growth characteristics and in turn influence the weed-suppressive ability (Mishra and Bhan, 1997; Rahman et al., 2017; Arefin et al., 2018). It has been reported that aromatic rice variety may vary for their yield and quality due to different management aspects (Hossain et al., 2008; Sarkar et al., 2014). But, the information regarding the performance of aromatic rice varieties of Bangladesh to various weed management practices are scarce in the literature. Therefore, this research work was accomplished to evaluate the response of selected aromatic fine rice varieties of Bangladesh to different herbicide based weed management practices compared to farmers' practices.

\section{Material and Methods}

\section{Experimental site}

The experiment was carried out at the Agronomy Field Laboratory and Weed Management Laboratory, Bangladesh Agricultural University, Mymensingh during the period from July to December 2015. The site belongs to the Old Brahmaputra Floodplain (Agroecological Zone 9) of Bangladesh. The experimental soil was characterized by non-calcareous dark gray floodplain soils. The land was well drained, medium high with silty-loam soil in texture $(20 \%$ sand, $67 \%$ silt and $13 \%$ clay) and having $\mathrm{pH} 6.5$. The organic matter content of the land is low $(1.96 \%)$ with bulk density of $1.35 \mathrm{~g} \mathrm{~cm}^{-3}$ (Islam et al., 2017). The site was characterized by high temperature, high humidity and heavy rainfall with occasional gusty wind in AprilSeptember (summer) and scanty rainfall associated with moderately low temperature during October-March (winter). Monthly total rainfall, average temperature and humidity of the experimental site during the study period from July to December 2015 are shown in Figure 1.

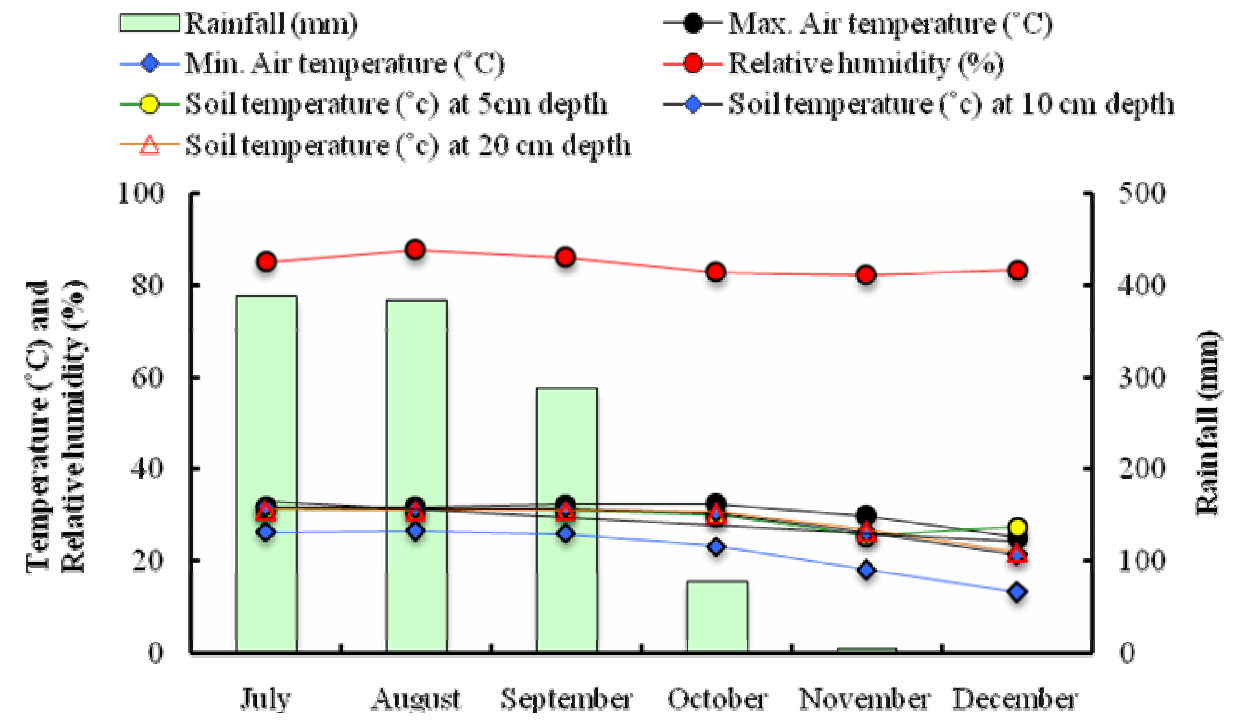

Figure 1. Monthly total rainfall, average temperature and humidity of the experimental site during the study period (July to December 2015) 
Treatments and design

The experiment was conducted with five aromatic fine rice varieties viz., Kalijira, BRRI dhan34, BRRI dhan37, BRRI dhan38 and Binadhan-13, and six weed management practices viz., no weeding (season long weedy), weed free (season long weed free), mechanical (by using weeder) + manual weeding (hand pulling), pre-emergence herbicide + manual weeding, postemergence herbicide + manual weeding and pre-- post- emergence herbicide. Here, pre-emergence herbicide (bensulfuran methyl + acetachlor@ @ $750 \mathrm{~g} \mathrm{ha}^{-1}$ ) was applied to the target plots at 5 days after transplantation (DAT) and post-emergence herbicide (pyrazosulfuron ethyl @ 125-150 $\mathrm{g} \mathrm{ha}^{-1}$ ) was applied to the target plots at 30 DAT. A brief description of the herbicides used in this experiment is presented in Table 1. The experiment was laid out in a randomized complete block design (RCBD) with three replications.

Table 1. A brief description of the herbicides used in this experiment

\begin{tabular}{lllllll}
\hline Trade name & Generic name & $\begin{array}{l}\text { Mode of } \\
\text { action }\end{array}$ & Selectivity & $\begin{array}{l}\text { Time of } \\
\text { application }\end{array}$ & Marketed by & Manufactured by \\
\hline Clean Master 18 wp & $\begin{array}{l}\text { Bensulfuran } \\
\text { methyl }+ \\
\text { Acetachlor }\end{array}$ & Systemic & $\begin{array}{l}\text { Selective for } \\
\text { grass and sedge } \\
\text { of rice }\end{array}$ & Pre-emergence & $\begin{array}{l}\text { Haychem } \\
\text { Bangladesh Ltd. }\end{array}$ & $\begin{array}{l}\text { Jhijiyang E-Tong } \\
\text { Chemical Co. Ltd., } \\
\text { China }\end{array}$ \\
\hline Tiraz 10 wp & $\begin{array}{l}\text { Pyrazosulfuron } \\
\text { ethyl }\end{array}$ & Systemic & $\begin{array}{l}\text { Selective for } \\
\text { weeds of rice }\end{array}$ & $\begin{array}{l}\text { Early post- } \\
\text { emergence }\end{array}$ & $\begin{array}{l}\text { Sweet Agrovet } \\
\text { Ltd. }\end{array}$ & $\begin{array}{l}\text { Reful Holding Co. } \\
\text { Ltd., China }\end{array}$ \\
\hline
\end{tabular}

\section{Crop husbandry}

Seeds of Kalijira were collected from the Agronomy Field Laboratory, Bangladesh Agricultural University, Mymensingh. Seeds of BRRI dhan34, BRRI dhan37 and BRRI dhan38 were collected from Bangladesh Rice Research Institute (BRRI) Gazipur, whereas seeds of Binadhan-13 were collected from Bangladesh Institute of Nuclear Agriculture (BINA), Mymensingh. Sprouted seeds of all the varieties were sown in five different wet nursery beds. Proper care was taken to raise the seedling in the nurseries. Transplanting of 30-day old seedlings was done in puddled soil on July 29, 2015. Rice varieties were fertilized with $150,97,70,60$ and $12 \mathrm{~kg} \mathrm{ha}^{-1}$ urea, triple super phosphate, muriate of potash, gypsum and zinc sulphate, respectively. All the fertilizers except urea were applied in the unit plots at the time of final land preparation. Urea was top-dressed in three equal splits at 30, 50 and 70 days after transplanting (DAT), Seedlings were transplanted in the plots according to the layout at the rate of three seedlings hill ${ }^{-1}$ maintaining $25 \mathrm{~cm} \times 15$ $\mathrm{cm}$ spacing. Rice was grown as rainfed crop since rainfall was sufficient. Intercultural operations e.g., gap filling, and drainage were done as per requirement. Plants were slightly infested with green leafhoppers, which were successfully controlled by spraying Karate 2.5 EC (Lamda Cyhalothrin@1 mLL $\mathrm{mL}^{-1}$ ) once at 20 DAT.

\section{Data recording and statistical analyses}

Weed species grown in the experimental field were identified and the summed dominance ratio (SDR) was calculated as per Hia et al. (2017):

$\mathrm{SDR}=\frac{\text { Relative density }(\mathrm{RD})+\text { Relative dry weight }(\mathrm{RDW})}{2} \times 100$

Where,

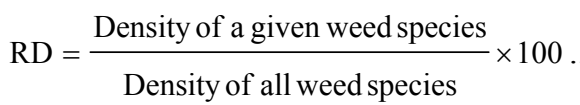

$$
\text { RDW }=\frac{\text { Dry weight of a given weed species }}{\text { Dry weight of all weed species }} \times 100
$$

The percent reduction of weed density (RWD) and reduction of weed biomass (RWB) were calculated as per the following formula:

$$
\begin{aligned}
& \% \mathrm{RWD}=1-\frac{\text { Number of weeds } \mathrm{m}^{-2} \text { in treated plots }}{\text { Number of weeds } \mathrm{m}^{-2} \text { in weedy plots }} \times 100 \\
& \ldots \mathrm{RWB}=1-\frac{\text { Number of weeds biomass } \mathrm{m}^{-2} \text { in treated plots }}{\text { Number of weeds biomass } \mathrm{m}^{-2} \text { in weedy plots }} \times 100
\end{aligned}
$$

Five hills (excluding border hills) were randomly selected in each plot and uprooted before harvesting for recording the yield contributing data as per Ray et al., (2015). The crops of central one square meter area from each plot were harvested and threshed by pedal thresher. The grains were sun dried and cleaned. Final grain weight was adjusted to $14 \%$ moisture content using the following formula:

$$
\% \text { Moisture }=\frac{\text { Fresh weight }- \text { Oven dry weight }}{\text { Fresh weight }} \times 100 \ldots .
$$

Adjusted yield at 14\% moisture content (MC)

$$
=\frac{\text { Fresh weight } \times(100-\% \mathrm{MC})}{(100-14)}
$$

Analysis of variance was done with the help of computer package MSTAT-C. The mean differences among the treatments were adjudged by Duncan's Multiple Range Test (Gomez and Gomez, 1984). 


\section{Results and Discussion}

Weed composition

The experimental field was infested with the naturally occurring weed community including grass, broad leaved and sedge weeds. The weed composition of the weedy plots is presented in Table 2 . Ten weed species belonging to five families (five grasses, three broadleaves and two sedges) were found growing in the experimental field. Based on the summed dominance ratio (SDR) values, grass weed species Echinochloa crusgalli (SDR of 30.7) was the most dominant species in the weedy plot followed by the broadleaf weed
Monochoria vaginalis (SDR of 25.1). On the other hand, the least dominant weed species was broadleaf weed Nymphaea nouchali (SDR of 0.83) followed by broadleaf weed species Marsilea crenata (SDR of 0.95) (Figure 2). Echinochloa crusgalli and Monochoria vaginalis dominated weed community in rice were also reported by Islam et al. (2017) and Popy et al. (2017) in the rice field at the same experimental site. In fact, weed community of a field is mostly determined by the soil seed bank, weed management in previous crops and the cropping pattern followed.

Table 2. Weed composition found in untreated weedy plots of the experimental field

\begin{tabular}{clll}
\hline $\begin{array}{c}\text { Sl. } \\
\text { No. }\end{array}$ & Scientific name & Family & Morphological type \\
\hline 1 & Echinochloa crusgalli (L.) Beauv. & Poaceae & Annual grass \\
2 & Cyperus difformis L. & Poaceae & Annual grass \\
4 & Digitaria sanguinalis L. & Poaceae & Annual grass \\
5 & Paspalum scrobiculatum L. & Poaceae & Perennial grass \\
6 & Leersia hexandra Sw. & Poaceae & Perennial grass \\
7 & Eleocharis atropurpurea (Retz.) J. \& K. Presl & Cyperaceae & Annual sedge \\
8 & Cyperus iria L. & Cyperaceae & Annual sedge \\
9 & Marsilea crenata C. Presl. & Marsileaceae & Annual broad leaf \\
10 & Nymphaea nouchali Burm. f. & Nymphaeaceae & Annual broad leaf \\
11 & Monochoria vaginalis (Burm. F.) C. Presl. & Pontederiaceae & Perennial broad leaf \\
\hline
\end{tabular}

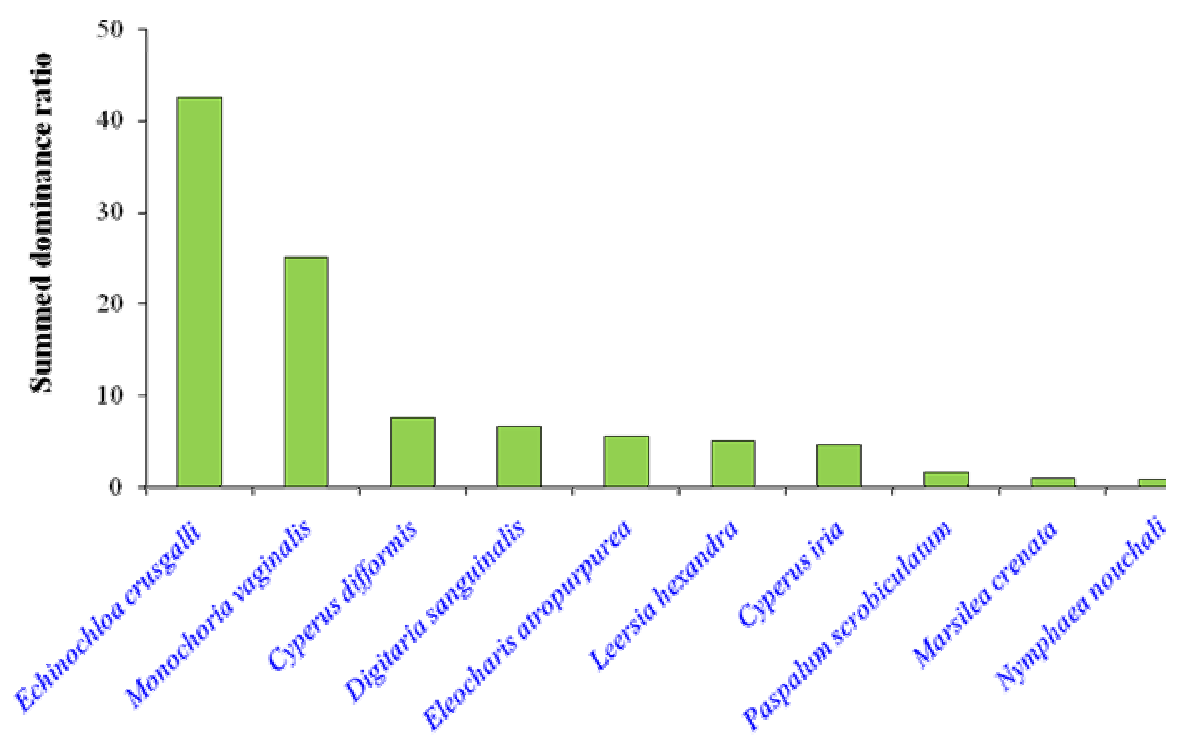

Weed species

Figure 2. Summed dominance ratio (SDR) of the major weeds found in weedy plots

\section{Percent reduction in weed density and biomass}

Variation in weed density and biomass reduction over control was observed among the weed management practices at different days after transplanting (DAT) (Table 3). At all sampling dates, weed free treatments gave the complete reduction in weed density and biomass $(100 \%)$ over control (weedy) because no weed was allowed to grow in weed free plots. As expected, the lowest percentage of weed density and biomass reduction $(0 \%)$ was noted in plots where weeds were allowed to compete with rice plants without adopting any weed management practices i.e., weedy plots. Apart from the weed free and weedy plots, the highest percentage of weed density $(76.5 \%)$ and biomass $(92.0 \%)$ reduction were observed in pre- + postemergence herbicide application, and the lowest was in post-emergence herbicide + manual weeding at $45 \mathrm{DAT}$ (Table 3). At 65 DAT, the highest percentage of reduction in weed density $(17.8 \%)$ and biomass $(50.7 \%)$ were observed in pre- + post-emergence herbicide 
application and the lowest weed density (7.3\%) was in post-emergence herbicide + manual weeding, and the lowest biomass $(33.1 \%)$ in pre-emergence herbicide + manual weeding. On the other hand, at $85 \mathrm{DAT}$, pre- + post-emergence herbicide application reduced highest percentage of weed density and biomass (43.2 and $48.6 \%$, respectively), while post-emergence herbicide + manual weeding reduced the lowest weed density $(22.5 \%)$ and mechanical weeding + manual weeding reduced the lowest weed biomass (1\%) (Table 3). Hia et al. (2017) also observed that pre- + post-emergence herbicide treatment had the highest weed control efficiency at all observations. Weed density and biomass at earlier stage of crop growth were more critical than later stage (Bedmar et al., 1999; Popy et al., 2017). Several researchers established the importance of time of emergence of the weeds (Ciuberkis et al., 2007; Singh et al., 2017). It has been reported that the weeds, which emerge simultaneously or shortly after the crop emergence cause severe yield losses at very low densities (Popy et al., 2017). Therefore, the treatment consisting of pre- + post-emergence herbicide can control weed more effectively at earlier stages of crop growth and hence can be considered as the most effective weed management practice.

\section{Yield contributing characters}

Number of effective tillers hill ${ }^{-1}$ was significantly affected by rice variety, different weed management and their interaction (Table 4, 5 and 6). Number of grains panicle $^{-1}$, weight of 1000-grain were significantly affected by rice variety and different weed management and not in their interaction, whereas panicle length was significantly influenced only by rice variety (Table 4,5 and 6). The highest number of effective tiller hill ${ }^{-1}(9.06)$ was found in BRRI dhan38, which was statistically identical with Binadhan-13 (8.72). The lowest number of effective tiller hill ${ }^{-1}$ (6.44) was found in Kalijira (Table 4). Significant variations in number of effective tillers hill ${ }^{-1}$ among the varieties were also reported by Ferdous et al.(2016). The highest number of effective tillers hill $^{-1}(9.80)$ was found in weed free treatment followed by pre-+post-emergence herbicide application. The lowest number of effective tiller hill ${ }^{-1}$ (5.27) was found in weedy plot (Table 5). The lowest number of effective tiller hill ${ }^{-1}$ was observed due to the severe cropweed competition in the weedy treatment whereas, the highest number was found in weed free treatment because of no crop-weed competition. Weeding reduced inter species competition between crop and weed thus facilitated efficient utilization of resources viz., sunlight, nutrient and moisture to produce effective tillers. The highest number of effective tillers hill ${ }^{-1}$ (11.67) was produced by BRRI dhan 38 and BINAdhan- 13 in weed free treatment which was statistically identical with (10.33) Binadhan-13 in pre-+ post-emergence herbicide application. The lowest number of effective tillers hill ${ }^{-1}$ (3.67) was produced by BRRI dhan34 and BRRI dhan37 in weedy treatment (Table 6).

Table 3. Percent reduction in weed density and biomass over control due to different weed management practices

\begin{tabular}{|c|c|c|c|c|c|c|}
\hline \multirow{2}{*}{ Weed management } & \multicolumn{3}{|c|}{ Weed density } & \multicolumn{3}{|c|}{ Weed biomass } \\
\hline & 45 DAT & 65 DAT & $85 \mathrm{DAT}$ & $45 \mathrm{DAT}$ & 65 DAT & 85 DAT \\
\hline No weeding & 0 & 0 & 0 & 0 & 0 & 0 \\
\hline Weed free & 100 & 100 & 100 & 100 & 100 & 100 \\
\hline Mechanical + manual weeding & 52.9 & 11.3 & 27.9 & 89.3 & 37.5 & 1.0 \\
\hline Pre-emergence herbicide + manual weeding & 72.3 & 11.9 & 37.0 & 90.9 & 33.1 & 27.4 \\
\hline Post-emergence herbicide + manual weeding & 43.7 & 7.3 & 22.5 & 89.2 & 44.3 & 6.0 \\
\hline Pre -+ post-emergence herbicide & 76.5 & 17.8 & 43.2 & 92.0 & 50.7 & 48.6 \\
\hline
\end{tabular}

Table 4. Effect of variety on yield contributing characters of aromatic rice

\begin{tabular}{lccccc}
\hline Variety & $\begin{array}{c}\text { No. of effective } \\
\text { tillers hill }\end{array}$ & $\begin{array}{c}\text { No. of grains } \\
\text { panicle }^{-1}\end{array}$ & $\begin{array}{c}\text { Panicle length } \\
(\mathrm{cm})\end{array}$ & $\begin{array}{c}\text { Weight of 1000- } \\
\text { grains }(\mathrm{g})\end{array}$ & $\begin{array}{c}\text { Harvest index } \\
(\%)\end{array}$ \\
\hline Kalijira & $6.4 \mathrm{c}$ & $144.8 \mathrm{c}$ & $23.4 \mathrm{bc}$ & $14.4 \mathrm{~d}$ & $25.8 \mathrm{c}$ \\
BRRI dhan34 & $7.6 \mathrm{~b}$ & $158.3 \mathrm{~b}$ & $25.6 \mathrm{a}$ & $12.4 \mathrm{e}$ & $29.6 \mathrm{~b}$ \\
BRRI dhan37 & $7.5 \mathrm{~b}$ & $149.6 \mathrm{bc}$ & $22.7 \mathrm{c}$ & $18.7 \mathrm{~b}$ & $29.3 \mathrm{~b}$ \\
BRRI dhan38 & $9.1 \mathrm{a}$ & $193.1 \mathrm{a}$ & $23.9 \mathrm{~b}$ & $20.1 \mathrm{a}$ & $33.9 \mathrm{a}$ \\
Binadhan-13 & $8.7 \mathrm{a}$ & $145.2 \mathrm{c}$ & $23.1 \mathrm{bc}$ & $17.5 \mathrm{c}$ & $33.2 \mathrm{a}$ \\
\hline CV $(\%)$ & 23.98 & 8.14 & 5.32 & 5.47 & 24.64 \\
\hline Level of significance & $* *$ & $* *$ & $* *$ & $* *$ &
\end{tabular}

In a column, values having similar letter do not differ significantly whereas values with dissimilar letter differ significantly as per DMRT. $* *=$ Significant at $1 \%$ level of probability, $*=$ Significant at $5 \%$ level of probability. 
Table 5. Effect of weed management on yield contributing characters of aromatic rice

\begin{tabular}{lccccc}
\hline Weed Management & $\begin{array}{c}\text { No. of } \\
\text { effective } \\
\text { tillers hill }{ }^{-1}\end{array}$ & $\begin{array}{c}\text { No. of } \\
\text { grains } \\
\text { panicle }^{-1}\end{array}$ & $\begin{array}{c}\text { Panicle } \\
\text { length (cm) }\end{array}$ & $\begin{array}{c}\text { Weight of } \\
1000- \\
\text { grain(g) }\end{array}$ & $\begin{array}{c}\text { Harvest } \\
\text { index (\%) }\end{array}$ \\
\hline No weeding & $5.3 \mathrm{~d}$ & $135.3 \mathrm{~d}$ & 23.8 & $15.7 \mathrm{c}$ & $24.7 \mathrm{c}$ \\
Weed free & $9.8 \mathrm{a}$ & $172.5 \mathrm{a}$ & 23.9 & $17.5 \mathrm{a}$ & $31.8 \mathrm{a}$ \\
Mechanical + Manual weeding & $7.9 \mathrm{c}$ & $155.1 \mathrm{c}$ & 23.8 & $16.6 \mathrm{~b}$ & $27.5 \mathrm{~b}$ \\
Pre-emergence herbicide + Manual weeding & $7.4 \mathrm{c}$ & $160.3 \mathrm{bc}$ & 23.4 & $16.4 \mathrm{~b}$ & $25.3 \mathrm{~b}$ \\
Post-emergence herbicide + Manual weeding & $8.1 \mathrm{bc}$ & $158.3 \mathrm{bc}$ & 23.6 & $16.8 \mathrm{~b}$ & $26.8 \mathrm{~b}$ \\
Pre-+ Post-emergence herbicide & $8.8 \mathrm{~b}$ & $167.7 \mathrm{ab}$ & 23.8 & $16.6 \mathrm{~b}$ & $30.7 \mathrm{a}$ \\
\hline CV (\%) & 13.25 & 8.14 & 5.69 & 5.41 & 8.42 \\
\hline Level of significance & $* *$ & $* *$ & $\mathrm{NS}$ & $* *$ & $* *$ \\
\hline
\end{tabular}

In a column, values having similar letter do not differ significantly whereas values with dissimilar letter differ significantly as per DMRT. $* *=$ Significant at $1 \%$ level of probability, NS= non-significant.

Table 6. Effect of variety and weed management interaction on yield contributing characters and yield of aromatic rice

\begin{tabular}{|c|c|c|c|c|c|c|c|c|}
\hline \multicolumn{2}{|r|}{ Interactions } & \multirow{2}{*}{$\begin{array}{c}\text { No. of } \\
\text { effective } \\
\text { tillers hill }\end{array}$} & \multirow{2}{*}{$\begin{array}{c}\text { No. of } \\
\text { grains } \\
\text { panicle }^{-1}\end{array}$} & \multirow{2}{*}{$\begin{array}{l}\text { Panicle } \\
\text { length } \\
(\mathrm{cm})\end{array}$} & \multirow{2}{*}{$\begin{array}{l}\text { Weight } \\
\text { of } 1000- \\
\text { grain }(\mathrm{g})\end{array}$} & \multirow{2}{*}{$\begin{array}{l}\text { Grain } \\
\text { Yield } \\
\left(\mathrm{t} \mathrm{ha}^{-1}\right)\end{array}$} & \multirow{2}{*}{$\begin{array}{c}\text { Straw } \\
\text { yield } \\
\left(\mathrm{t} \mathrm{ha}^{-1}\right)\end{array}$} & \multirow{2}{*}{$\begin{array}{c}\text { Harvest } \\
\text { index } \\
(\%)\end{array}$} \\
\hline$\stackrel{\frac{D}{0}}{\frac{D}{\pi}}$ & Weed Management & & & & & & & \\
\hline \multirow{6}{*}{ 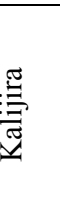 } & No weeding & $5.7 \mathrm{~h}$ & 132.7 & 23.8 & 13.9 & $1.0 \mathrm{klm}$ & 3.0 & 25.3 \\
\hline & Weed free & $7.7 \mathrm{c}-\mathrm{g}$ & 170.7 & 22.9 & 14.8 & $2.4 \mathrm{f}-\mathrm{j}$ & 5.6 & 29.7 \\
\hline & Mechanical + Manual weeding & $6.0 \mathrm{gh}$ & 159.0 & 23.3 & 14.4 & $1.1 \mathrm{jkl}$ & 3.6 & 23.6 \\
\hline & Pre-emergence herbicide + Manual weeding & $6.0 \mathrm{gh}$ & 163.7 & 23.4 & 14.3 & $1.3 \mathrm{i}-1$ & 3.9 & 24.2 \\
\hline & Post-emergence herbicide + Manual weeding & $6.3 \mathrm{fgh}$ & 156.0 & 23.6 & 14.4 & $1.3 \mathrm{i}-1$ & 4.8 & 20.9 \\
\hline & Pre -+ Post-emergence herbicide & 7.0d-h & 167.7 & 23.5 & 14.3 & $1.8 \mathrm{~h}-\mathrm{k}$ & 4.4 & 29.1 \\
\hline \multirow{6}{*}{ 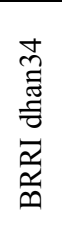 } & No weeding & $3.7 \mathrm{i}$ & 163.0 & 23.9 & 11.9 & $0.7 \mathrm{~m}$ & 2.6 & 20.8 \\
\hline & Weed free & $9.0 \mathrm{bcd}$ & 215.7 & 26.2 & 12.9 & $3.2 \mathrm{c}-\mathrm{g}$ & 6.1 & 33.9 \\
\hline & Mechanical + Manual weeding & $8.0 \mathrm{c}-\mathrm{f}$ & 182.7 & 25.8 & 12.4 & $2.1 \mathrm{hij}$ & 5.2 & 29.1 \\
\hline & Pre-emergence herbicide + Manual weeding & $8.0 \mathrm{c}-\mathrm{f}$ & 192.3 & 25.0 & 12.3 & $2.3 g-j$ & 5.4 & 29.5 \\
\hline & Post-emergence herbicide + Manual weeding & $8.3 \mathrm{cde}$ & 201.0 & 26.2 & 12.3 & $2.7 e-i$ & 6.0 & 31.1 \\
\hline & Pre- + Post-emergence herbicide & $8.7 \mathrm{bcd}$ & 203.7 & 26.1 & 12.4 & $2.9 \mathrm{~d}-\mathrm{h}$ & 5.8 & 33.6 \\
\hline \multirow{6}{*}{ 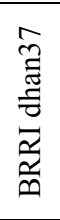 } & No weeding & $3.7 \mathrm{i}$ & 133.0 & 23.4 & 17.4 & 2.01 & 6.7 & 23.2 \\
\hline & Weed free & $9.0 \mathrm{bcd}$ & 163.7 & 23.1 & 19.1 & $2.7 \mathrm{~cd}$ & 5.6 & 32.2 \\
\hline & Mechanical + Manual weeding & $7.7 \mathrm{c}-\mathrm{g}$ & 156.0 & 23.4 & 18.7 & $2.2 \mathrm{~d}-\mathrm{h}$ & 5.5 & 28.9 \\
\hline & Pre-emergence herbicide + Manual weeding & $8.3 \mathrm{cde}$ & 145.7 & 21.9 & 18.7 & $2.3 \mathrm{~d}-\mathrm{h}$ & 5.1 & 30.9 \\
\hline & Post-emergence herbicide + Manual weeding & $8.0 \mathrm{c}-\mathrm{f}$ & 141.0 & 21.5 & 18.9 & $2.4 \mathrm{e}-\mathrm{h}$ & 5.8 & 29.7 \\
\hline & Pre- + Post-emergence herbicide & $8.3 \mathrm{cde}$ & 158.0 & 22.90 & 19.3 & $2.3 \mathrm{efg}$ & 5.1 & 31.3 \\
\hline \multirow{6}{*}{ 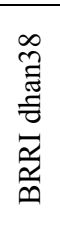 } & No weeding & $7.7 \mathrm{c}-\mathrm{g}$ & 130.0 & 24.9 & 18.8 & $2.2 \mathrm{~g}-\mathrm{j}$ & 5.4 & 29.1 \\
\hline & Weed free & $11.7 \mathrm{a}$ & 156.3 & 23.9 & 22.0 & $3.7 \mathrm{a}$ & 6.4 & 36.7 \\
\hline & Mechanical + Manual weeding & $9.3 \mathrm{bc}$ & 135.0 & 24.1 & 20.4 & $3.0 \mathrm{c}-\mathrm{f}$ & 6.8 & 30.6 \\
\hline & Pre-emergence herbicide + Manual weeding & $8.0 \mathrm{c}-\mathrm{f}$ & 146.7 & 23.5 & 19.9 & $3.3 \mathrm{c}-\mathrm{h}$ & 6.7 & 32.8 \\
\hline & Post-emergence herbicide + Manual weeding & $8.0 \mathrm{c}-\mathrm{f}$ & 150.0 & 23.5 & 19.5 & $3.2 \mathrm{c}-\mathrm{h}$ & 7.6 & 29.7 \\
\hline & Pre- - Post-emergence herbicide & $9.7 \mathrm{bc}$ & 153.3 & 23.4 & 20.0 & $3.4 \mathrm{bc}$ & 6.2 & 35.7 \\
\hline \multirow{8}{*}{ 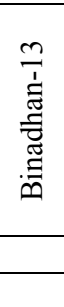 } & No weeding & $5.7 \mathrm{~h}$ & 117.7 & 22.9 & 16.3 & $1.1 \mathrm{klm}$ & 4.0 & 20.7 \\
\hline & Weed free & $11.7 \mathrm{a}$ & 156.0 & 23.3 & 18.8 & $3.6 \mathrm{ab}$ & 5.7 & 38.7 \\
\hline & Mechanical + Manual weeding & $8.3 \mathrm{cde}$ & 143.0 & 22.5 & 17.2 & $2.4 \mathrm{f}-\mathrm{i}$ & 5.6 & 29.7 \\
\hline & Pre-emergence herbicide + Manual weeding & $6.7 \mathrm{e}-\mathrm{h}$ & 153.3 & 23.5 & 16.7 & $1.9 \mathrm{~h}-\mathrm{k}$ & 5.1 & 26.8 \\
\hline & Post-emergence herbicide + Manual weeding & $9.7 \mathrm{bc}$ & 143.3 & 23.2 & 18.9 & $2.2 \mathrm{c}-\mathrm{f}$ & 5.7 & 28.1 \\
\hline & Pre- + Post-emergence herbicide & $10.3 \mathrm{ab}$ & 155.7 & 23.3 & 17.1 & $2.5 \mathrm{cde}$ & 5.2 & 32.7 \\
\hline & $\mathrm{CV}(\%)$ & 13.9 & 13.9 & 5.5 & 10.0 & 5.5 & 6.9 & 5.7 \\
\hline & Level of significance & $*$ & NS & NS & NS & $*$ & NS & NS \\
\hline
\end{tabular}

In a column, values having similar letter do not differ significantly whereas values with dissimilar letter differ significantly as per DMRT. ${ }^{*}=$ Significant at $5 \%$ level of probability, $\mathrm{NS}=$ non-significant

The highest number of grains panicle ${ }^{-1}$ (193.1) was found in BRRI dhan38. The lowest number of grains panicle $^{-1}$ (144.8) was found in Kalijira, which was statistically identical with Bina dhan-13 (145.2) and BRRI dhan37 (Table 4). Variable number of grains panicle $^{-1}$ among the varieties was also observed by Sarkar et al. (2014). Varietal variation regarding the number of grains panicle ${ }^{-1}$ might be due to their variation in genetic constitution. The highest number of grains panicle ${ }^{-1}$ (172.5) was found in weed free 
condition which was statistically identical with (167.7) pre- + post-emergence herbicide application. The lowest number of grains panicle ${ }^{-1}(135.3)$ was found in weedy plots (Table 5). Similar results were also reported by Paul et al. (2015) and Khan et al. (2017). They reported that the highest number of grains panicle ${ }^{-1}$ was produced in the weed free condition in rice. Number of grains panicle ${ }^{-1}$ was not significantly affected by interaction between variety and weed management (Table 6).

The longest panicle $(25.6 \mathrm{~cm})$ was produced by BRRI dhan 34, whereas the shortest one $(22.7 \mathrm{~cm})$ by BRRI dhan37 (Table 4). Sarkar et al., (2014) also found the higher panicle length in BRRI dhan34 than the BRRI dhan37 and BRRI dhan38. Panicle length was not significantly affected by weed management and its interaction with varieties (Table 5 and 6). The variation of panicle length is due to the genetic makeup of the varieties (Ifftikhar et al., 2009).

The highest 1000-grain weight (20.1 g) was produced by BRRI dhan38. The lowest weight of 1000-grain (12.35 g) was produced by BRRI dhan34 followed by Kalijira $(14.4 \mathrm{~g})$ (Table 4). The variations in the weight of 1000grain could be due the differences in the grain size among the varieties. Baloch et al. (2002) and Saha et al. (2015) also found the variations in the weight of 1000grain within varieties. The highest weight of 1000-grain $(17.5 \mathrm{~g})$ was found in weed free condition. The lowest weight of 1000-grain $(15.7 \mathrm{~g})$ was found in weedy plot (Table 5). The result was similar to the findings of Ganeshwor and Gadadhar (2000). Khan and Tarique (2011) and Popy et al. (2017) also obtained heavier grains from weed free plots, this is because 1000-grain weight is negatively related to weed density (Karim and Ferdous, 2010). Khan et al. (2017) found that no weeding reduced 1000-grain weight significantly. Weight of 1000-grains was not significantly affected by interaction of variety and weed management (Table 6).

\section{Yield}

Yield of aromatic rice was significantly affected by rice variety, different weed management and in their interaction except straw yield in case of their interaction (Figure 3, 4 and Table 6). The highest grain yield (3.4 t $\mathrm{ha}^{-1}$ ) was produced by BRRI dhan 38 . The lowest grain yield $\left(1.5 \mathrm{t} \mathrm{ha}^{-1}\right)$ was produced by Kalijira (Figure 3). Similar results were found elsewhere (Islam et al., 2012; Tyeb et al., 2013), who reported that variety exerted variable effect on yield contributing characters and yield of rice. Differences in grain yield due to varieties were also reported by Yoshida (1994) and Siddeque et al. (2002). The highest grain yield $\left(3.2 \mathrm{tha}^{-1}\right)$ was found in weed free treatment followed by pre- + post-emergence herbicide application $\left(2.5 \mathrm{tha}^{-1}\right)$. The lowest grain yield $\left(1.4 \mathrm{t} \mathrm{ha}^{-1}\right)$ was found in no weeding treatment (Figure 4). The highest grain yield $\left(3.7 \mathrm{t} \mathrm{ha}^{-1}\right)$ was found in BRRI dhan38 in weed free treatment, which was statistically identical with Binadhan-13 $\left(3.6 \mathrm{t} \mathrm{ha}^{-1}\right)$ in the same treatment. The lowest grain yield $\left(0.7 \mathrm{t} \mathrm{ha}^{-1}\right)$ was produced by BRRI dhan34 in weedy plot, which was statistically identical with Binadhan-13 $\left(1.1 \mathrm{t} \mathrm{ha}^{-1}\right)$ and Kalijira $\left(1.02 \mathrm{t} \mathrm{ha}^{-1}\right)$ in the same condition (Table 6). Other than the weedy and weed free treatments, the highest grain yield $\left(3.4 \mathrm{t} \mathrm{ha}^{-1}\right)$ was obtained from BRRI dhan38 with pre- + post-emergence herbicide application. The highest yield in this treatment could be due to the higher number of effective tillers hill ${ }^{-1}$. Mahajan and Chauhan (2015) stated that the time window for the application of pre-emergence herbicide is very narrow and sometimes, farmers miss the optimum time application. Therefore, sequential applications of pre- + post-emergence herbicides provided better control of early and late flushes of weeds than the sole application (Mahajan and Chauhan, 2013).

The highest straw yield $\left(6.5 \mathrm{t} \mathrm{ha}^{-1}\right)$ was produced by BRRI dhan38, which was statistically identical with Binadhan-13 (5.9 t ha $\left.{ }^{-1}\right)$. The lowest straw yield $(4.2 \mathrm{t}$ $\mathrm{ha}^{-1}$ ) was produced by Kalijira, which was statistically identical with BRRI dhan34 (5.2 $\left.\mathrm{t} \mathrm{ha}^{-1}\right)$ (Figure 3). The highest straw yield $\left(6.9 \mathrm{t} \mathrm{ha}^{-1}\right)$ was found in weed free treatment which was statistically identical with postemergence herbicide + manual weeding $\left(6.5 \mathrm{t} \mathrm{ha}^{-1}\right)$, preemergence herbicide + manual weeding $\left(6.1 \mathrm{t} \mathrm{ha}^{-1}\right)$, mechanical + manual weeding $\left(5.8 \mathrm{t} \mathrm{ha}^{-1}\right)$ and pre-post-emergence herbicides $\left(5.7 \mathrm{t} \mathrm{ha}^{-1}\right)$ (Figure 4). The lowest straw yield $\left(4.2 \mathrm{t} \mathrm{ha}^{-1}\right)$ was found in no weeding treatment (Figure 4). Straw yield was not significantly affected by the interaction of variety and weed management (Table 6).

\section{Harvest index (\%)}

Similar to some other yield contributing characters harvest index was significantly affected by rice variety and different weed management but not by their interaction (Table 4, 5 and 6). The highest harvest index (33.9\%) was obtained in BRRI dhan38 which was statistically identical with Binadhan-13 (33.2\%). The lowest harvest index (25.8\%) was observed in Kalijira (Table 4). Pre- + post-emergence herbicide application gave the highest harvest index $(31.8 \%)$, which was statistically identical with weed free treatment (30.7\%). The lowest harvest index (24.7\%) was observed in weedy plot (Table 5). Harvest index was not significantly affected by interaction between variety and weed management (Table 6). 


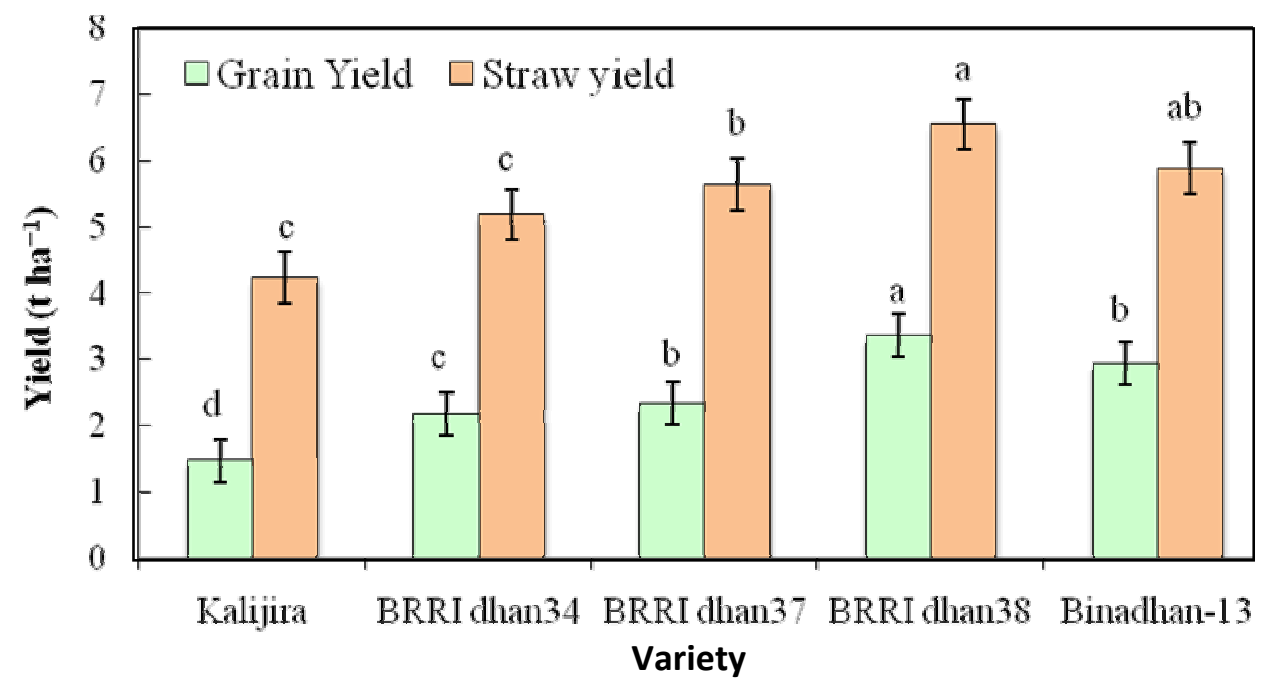

Figure 3. Grain and straw yield of aromatic rice as influenced by variety

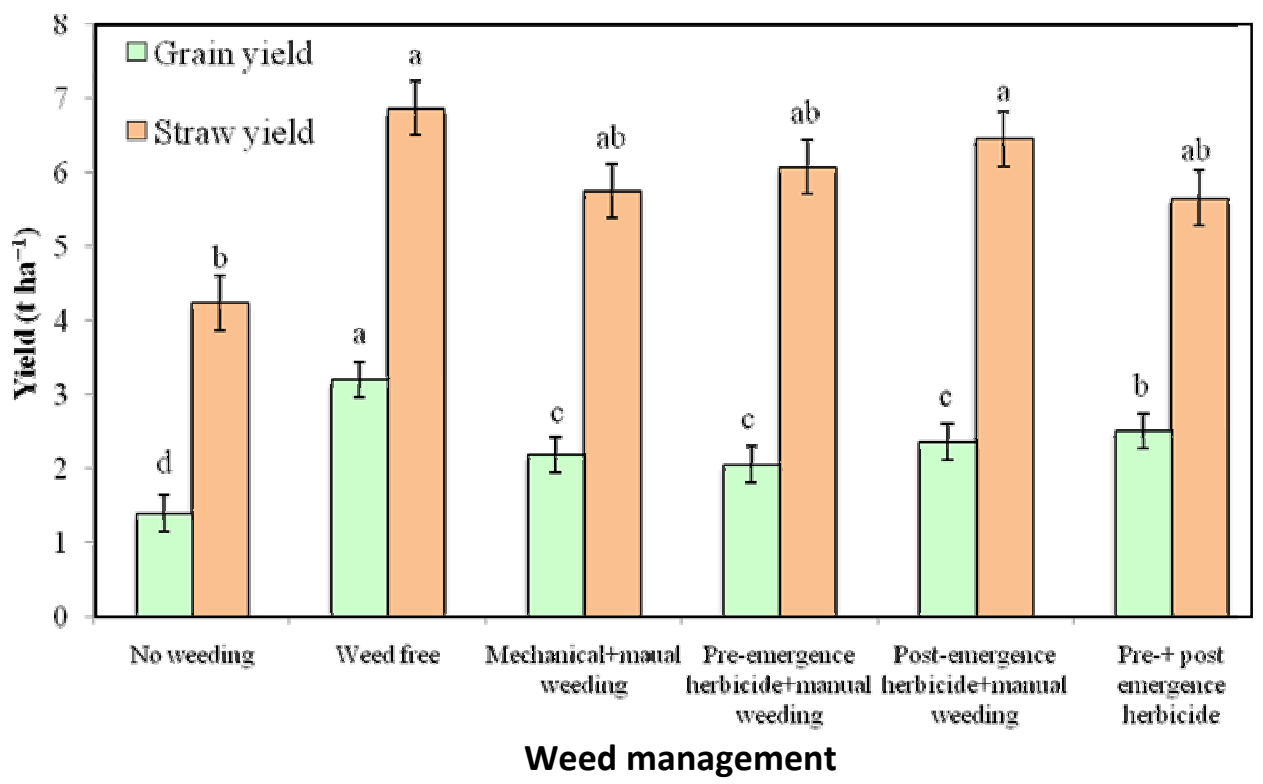

Figure 4. Grain and straw yields of aromatic rice as influenced by weed management

\section{Conclusion}

Weed management is challenging task in agriculture to maintain crop yield and productivity. This fact is also true for aromatic fine rice, as it is one of the factors responsible for lowering the grain yield. However, very little research has been conducted in aromatic fine rice of Bangladesh as well as their weed management. Farmers mainly practiced either conventional (manual or mechanical) or chemical means of weed control. In the current research it was observed the recent released varieties performed very well in respect of yield than the old variety Kalijira. Among the tested herbicides, pre- + post-emergence herbicide performed very well in controlling weeds compared to other methods of weed control. However, this experiment was conducted only in one location and one year. Multi-location trials for several years should be conducted before recommending the package to the farmers. Moreover, environmental issues related to herbicide use should be brought under consideration. Because, farmers sometimes ignore the instructions and do not use the correct volume of spray, dose and spray nozzle, which lead to poor weed suppression. In that case farmers may integrate pre- or post-emergence herbicide with a manual weeding considering both the environmental and labour cost issues.

\section{Conflict of Interest}

The authors declare that there is no conflict of interests regarding the publication of this paper.

\section{References}

Abbas, T., Zahir, Z.A., Naveed, M. and Kremer, R.J. 2018. Limitations of existing weed control practices necessitate development of alternative techniques based on biological approaches. Adv. Agron. 147: 239-280.

Aktar, M.W., Sengupta, D. and Chowdhury, A. 2009. Impact of Pesticides Use in Agriculture: Their Benefits and Hazards. Interdisc. Toxicol. 2: 1-12. 
Anwar, M.P., Juraimi, A.S., Puteh, A., Man, A. and Rahman, M.M. 2012. Efficacy, phytotoxicity and economics of different herbicides in aerobic rice, Acta Agr. Scand. B-S P. 62(7): 604-615.

Arefin, M.A., Rahman, M.R., Rahman, A.N.M.A., Islam A.K.M.M. and Anwar, M.P. 2018. Weed competitiveness of winter rice (Oryza sativa L.) under modified aerobic system. Arch. Agr. Environ. Sci.3(1): 1-14.

Ashiq, M. and Aslam, Z. 2014. Chemical control of weeds. In: weeds and weedicides. Department of Agronomy, Ayub Agricultural Research Institute, Faisalabad and University of Agriculture, Faisalabad, Pakistan, p. 235 - 256.

Baloch, A.W., Soomro, A.M., Javed, M.A., Ahmed, M., Bughio, H.R., Bughio, M.S. and Mastoi, N.N. 2002. Optimum plant density for high yield in rice (Oryza sativa L.). Asian J. Plant Sci. 1(1): 25-27.

BBS (Bangladesh Bureau of Statistics). 2017. Statistical Yearbook of Bangladesh. Bangladesh Bureau of Statistics, Ministry of Planning. Dhaka. Bangladesh.

Bedmar, F., Manetti, P. and Monterubbianesi, G. 1999. Determination of the critical period of weed control in corn using a thermal basis. Pesq. Agropec. Bras. 34 (2): 187-193.

Biswas, T., Paul, S.K., Sarkar, M.A.R. and Sarkar, S.K. 2016. Integrated use of poultry manure with prilled urea and urea super granules for improving yield and protein content of aromatic rice (cv. BRRI dhan50). Progress. Agric. 27 (2): 86-93.

BRRI (Bangladesh Rice Research Institute). 2008. Annual Report for 2007. Bangladesh Rice Res. Inst. Joydevpur, Gazipur, p. $28-35$.

Chauhan, B.S., and Johnson, D.E. 2011. Row spacing and weed control timing affect yield of aerobic rice. Field Crops Res. 121: 226-231.

Ciuberkis, S., Bernotas, S., Raudonius, S. and Felix, J. 2007. Effect of weed emergence time and intervals of weed and crop competition on potato yield. Weed Technol. 21: 612-617.

Ferdous J., Islam, N., Salam, M.A. and Hossain, M.S. 2016. Effect of weed management practices on the performance of transplanted aman rice varieties. J. Bangladesh Agril. Univ.14(1): 17-22.

Ganeshwor, T. and Gadadhar, M. 2000. Effectiveness of herbicides on controlling weeds in transplanted rice. Nio-Botanica. $8(1 \& 2): 1-6$

Gomez, K.A and Gomez, A.A. 1984. Statistical procedures for agricultural research. Int. Rice Res. Inst., John Wiley and Sons. New York, Chichester, Brisbane, Toronto, Singapore, p. 680 .

Hasanuzzaman, M., Ali, M.H., Alam, M.M., Akther, M. and Alam, K.F. 2009. Evaluation of pre-emergence herbicide and hand weeding on the weed control efficiency and performance of transplanted aus rice. American-Eurasian J. Agron. 2: 138 143.

Heap I. 2018. The international survey of herbicide resistant weeds. Online internet. Corvallis (OR): Ian Heap; [cited 2018 February 12]. Available from: www.weedscience.org

Hia, M.A.U.H., Islam, A.K.M.M., Sarkar, S.K. and Anwar, M.P. 2017. Effectiveness of integrated weed management in five varieties of aromatic rice in Bangladesh. Arch. Agr. Environ. Sci. 2(3): 308-314

Holt, J.S. 1994. Impact of weed control on weeds: new problems and research needs. Weed Technol. 8: 400-402.

Hossain, M.F., Islam, M.S., Rahman, M.M., Faruk, M.O. and Ershad, M.G. 2008. Yield and quality performance of some aromatic rice varieties of Bangladesh. J. Agrofor. Environ. 2(2): $155-158$.

Ifftikhar, J., Khalil, H., Abdul, B., Sajid, K. and Islam, Z. 2009. Genetic variation for yield and yield components in rice. ARPN J. Agril. Biol. Sci. 4 (6): 60-64.

Islam, A.K.M.M., Popy, F.S., Hasan, A.K. and Anwar, M.P. 2017. Efficacy and economics of herbicidal weed management in monsoon rice of Bangladesh. J. Sci. Agric. 1: 275-293.

Islam, M.S., Sarkar, M.A.R., Uddin, S. and Parvin, S. 2012. Yield of fine rice varieties as influenced by integrated management of poultry manure, urea super granules and prilled urea. $\mathrm{J}$. Environ. Sci. Nat. Res. 5(1): 129-132.

Islam, A.K.M.M. and Kato-Noguchi, H. 2014. Phytotoxic Activity of Ocimum tenuiflorum extracts on germination and seedling growth of different plant species. Sci. World J., 2014: 1-8.

Jabran, K. and Chauhan B.S. 2015. Weed management in aerobic rice systems. Crop Prot. 78: 151-163.

Jabran, K., Mahajan, G., Sardana, V. and Chauhan, B.S. 2015. Allelopathy for weed control in agricultural systems. Crop Prot. 72: $57-65$.

Karim, S.M.R. and Ferdous, M.N. 2010. Density effects of grass weeds on the plant characters and grain yields of transplanted aus rice. Bangladesh J. Weed Sci. 1(1): 49-54.

Khan, M.Z.K., Hasan, A.K., Anwar, M.P. and Islam, M.S. 2017. Weeding regime and plant spacing influence on weed growth and performance of transplant aman rice variety Binadhan-7. Fundam. Appl. Agric. 2(3): 331-339.

Khan, T.A. and Tarique, M.H. 2011. Effects of weeding regime on the yield and yield contributing characters of transplant aman rice. Int. J. Sci. and Advan. Technol. 11: 11-14.

Koch, W. 1992. Impact of weeds on developing countries. Proceedings of the First International Weed Control Congress, Melbourne, Australia, pp.127.

Mahajan G. and Chauhan, B.S. 2015. Weed control in dry directseeded rice using tank mixtures of herbicides in South Asia. Crop Prot. 5: 90-96.

Mahajan, G. and Chauhan, B.S. 2013. Herbicide options for weed control in dry-seeded aromatic rice in India. Weed Technol. 27(4): 682-689.

Mahajan, G., Chauhan, B.S. and Johnson, D.E. 2009. Weed management in aerobic rice in northwestern Indo-Gangetic plains. J. Crop Improv. 23: 366-382.

Mamun, A.A. 1990. Weeds and their control: A review of weed research in Bangladesh. Agricultural and Rural Development in Bangladesh. Japan Intl. Co-operation Agency. Dhaka, Bangladesh. JSARD. 19: 45-72.

Mishra, J.S. and Bhan, V.M. 1997. Effect of cultivar and weed control on weed growth and yield of pea (Pisumsativum). Indian J. Agron., 42(2): 316-319.

Monaco, T.J., Weller, S.C. and Ashton, F.M. 2002. Weed science principles and practices. $4^{\text {th }}$ edn. New York: John Wiley \& Sons, p. 3-126.

Paul, S.K, Islam, S.M.M., Sarkar, M.A.R., Alam, A. and Zaman, F. 2014. Physiological parameters of transplant Aman rice (cv. BRRI dhan49) as influenced by weeding regime and integrated nutrient management. J. Agrofor. Environ. 8(2): $121-125$.

Popy, F.S., Islam, A.K.M.M., Hasan, A.K. and Anwar, M.P. 2017. Integration of chemical and manual control methods for sustainable weed management in inbred and hybrid rice. $\mathrm{J}$ Bangladesh Agril. Univ., 15(2): 158-166.

Rahman, A.N.M.A., Islam, A.K.M.M., Arefin, M.A., Rahman, M.R. and Anwar M.P. 2017. Competitiveness of winter rice varieties against weed under dry direct seeded conditions. Agricl. Sci. 8(12): 1-24.

Raju, R.A. and Reddy, M.N. 2000. Effect of urea amended neem triferpens jelly, $\mathrm{N}$ rates and time of application on winter rice (Oryza sativa). Indian J. Agron. 42 (2): 278-281.

Rao, S. Principles of weed science $2^{\text {nd }}$ edn. 2000. New York: Science Publishers, $526 \mathrm{p}$.

Rashid, M.H., Uddin, M.H., Islam, A.K.M.M., Alam, A.H.M.J. and Anwar, M.P. 2007. Efficiencies and economics of some weed control methods in transplant aman rice cv. BRRI dhan32. Bangladesh J. Crop Sci. 18: 259-264.

Ray, S., Sarkar, M.A.R., Paul, S.K., Islam, A.K.M.M. and Yeasmin, S. 2015. Variation of growth, yield and protein content of transplant Aman rice by three agronomic practices. Agril. Biol. Sci. J. 1 (4): 167-176.

Saha, P.S., Islam, M.U., Islam, M.S. and Salam, M.A. 2015. Analysis of yield components and aroma of small grain aromatic rice (Oryza sativa L.) in Bangladesh. Agriculturists 13(2): 1724 
Sarkar, S.K., Sarkar, M.A.R., Islam, N. and Paul, S.K. 2014. Yield and quality of aromatic fine rice as affected by variety and nutrient management J. Bangladesh Agril. Univ. 12(2): 279-284.

Siddeque, S., Hossain, G., Ahmed, S.Q. and Farhad, A. 2002. Genotypic performance of rice in Pukhal of Mansehra, Sarhad. J. Agric. 18 (1): 49-52.

Sikdar, M.S.I., Rahman, M.M., Islam, M.S., Yeasmin, M.S. and Akhter, M.M. 2008. Effect of nitrogen level on aromatic rice varieties and soil fertility status. Int. J. Sustain. Crop Prod. 3 (3): 49-54.

Singh, M., Bhullar, M.S. and Chauhan, B.S. 2017. Relative time of weed and crop emergence is crucial for managing weed seed production: A study under an aerobic rice system. Crop Prot. 99: 33-38.
Singh, S., Ladha, J., Gupta, R., Bhushan, L. and Rao, A. 2008. Weed management in aerobic rice systems under varying establishment methods. Crop Prot. 27: 660-671.

Tanchotikul, U. and Hsieh, T.C.Y. 1991. An improved method for quantification of 2-acetyl-1-pyrroline a popcorn-like aroma, in aromatic rice by higher solution gas chromatography/ mass chromatography/selected ion monitoring. J. Agric. Food Chem., 39: 944-947.

Tyeb, A., Paul, S.K. and Samad, M.A. 2013. Performance of variety and spacing on the yield and yield contributing characters of transplanted aman rice. J. Agrofor. Environ. 40(4): 595597.

Yoshida, S. 1994. Fundamentals of Rice Crop Science. Intl. Rice Res. Inst. Manila, Philippines, pp.1-3. 